\title{
Jurassic Intrusives of the Coyote Mountains, western Salton Trough, southern California and their relationship to the Nazas Arc of northern Mexico.
}

George J Morgan (georgemorgan@cox,net) and J R Morgan

\section{Abstract}

Zircon $\mathrm{U} / \mathrm{Pb}$ dates from several granitic intrusives found in the Coyote Mountains (CMs) range from 164.1 to $138.9 \mathrm{Ma}$. The CMs magmatic activity is too early to be associated with the Cretaceous magmatic activity of the Peninsular Ranges Batholith ( 128 to $92 \mathrm{Ma}$ ) (Hildebrand and Whalen, 2014b and references therein) but is in the age range of the magmatic activity associated with the Jurassic part of the Nazas Arc in northern Mexico (State of Sonora). The Nazas Arc in Sonora is comprised of two episodes of tectonic activity: an earlier episode from 275 to $221 \mathrm{Ma}$ and a second (Jurassic) episode from 190 to $150 \mathrm{Ma}$. (González-León et al., 2017 and references therein).

The earliest normal faulting that represents a possibly detachment below the CMs is older than 17 Ma: an age consistent with Early Miocene extensional tectonics of the Basin and Range in Sonora. Extensional tectonics and subsidence continue to affect the CMs until the start of right-lateral transtensional faulting and uplift associated with the reorganization of the San Andres Fault System at $\sim 1.1 \mathrm{Ma}$ (Steely et al., 2009). With extension of the Basin and Range in Sonora, followed by right-lateral transtensional faulting, the CMs left Sonora and arrive in the western Salton Trough, next to the Peninsular Ranges Batholith (Morgan and Morgan, 2018b).

Morgan, G. J., and Morgan, J. R., 2019, Jurassic Intrusives of the Coyote Mountains, western Salton Trough, southern California and their relationship to the Nazas Arc or northern Mexico: Geological Society of America Abstracts with Programs. Vol. 51, No. 4. 


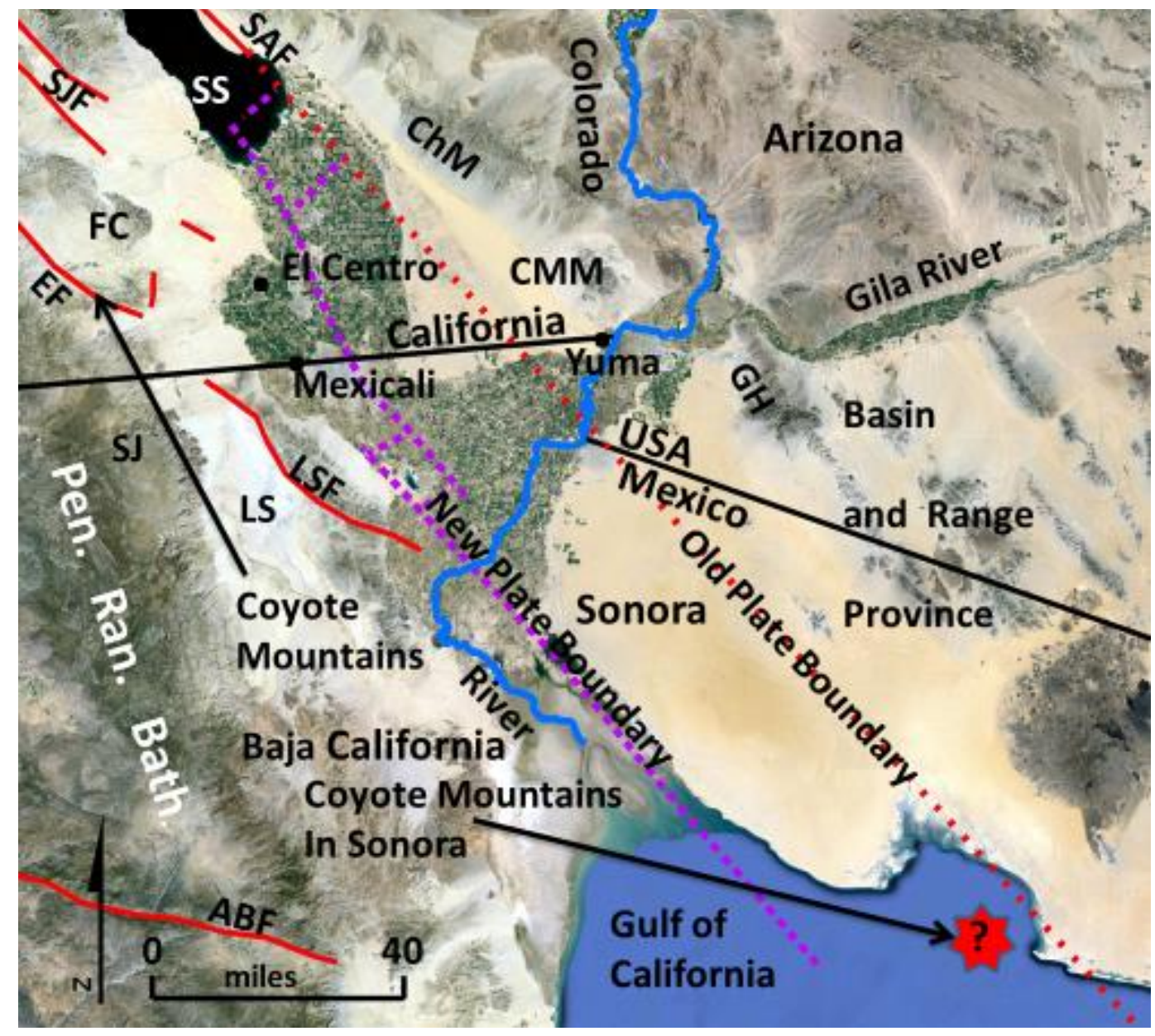

Figure 1. Location map of the Salton Trough and the Coyote Mountains in California, Arizona, Baja California and Sonora, Mexico. The Salton Trough, an northern extension of the Gulf of California, is bounded by the San Andreas Fault and Old Plate Boundary to the east and, for the most part, by the Peninsular Ranges Batholoth to the west. ABF - Agua Blanca Fault, ChM - Chocolate Mountains, CMM - Cargo Muchacho Mountains, EF Elsinore Fault, FC - Fish Creek Mountains, GM - Gila Mountains, LA Laguna Sallada, LSF - Laguna Salada Fault, Pen. Ran. Bath. - Peninsular Ranges Batholith, SAF - San Andreas Fault, SJ - Sierra de Juarez, SJF - San Jacinto Fault, SS - Salton Sea. Red star with query is the paleogeographic location of the Coyote Mountains at 5.5 Ma by Winker and Kidwell (1996) in Sonora, Mexico. We agree the paleogeographic location for the CMs was somewhere in Sonora, Mexico. NASA photograph. 


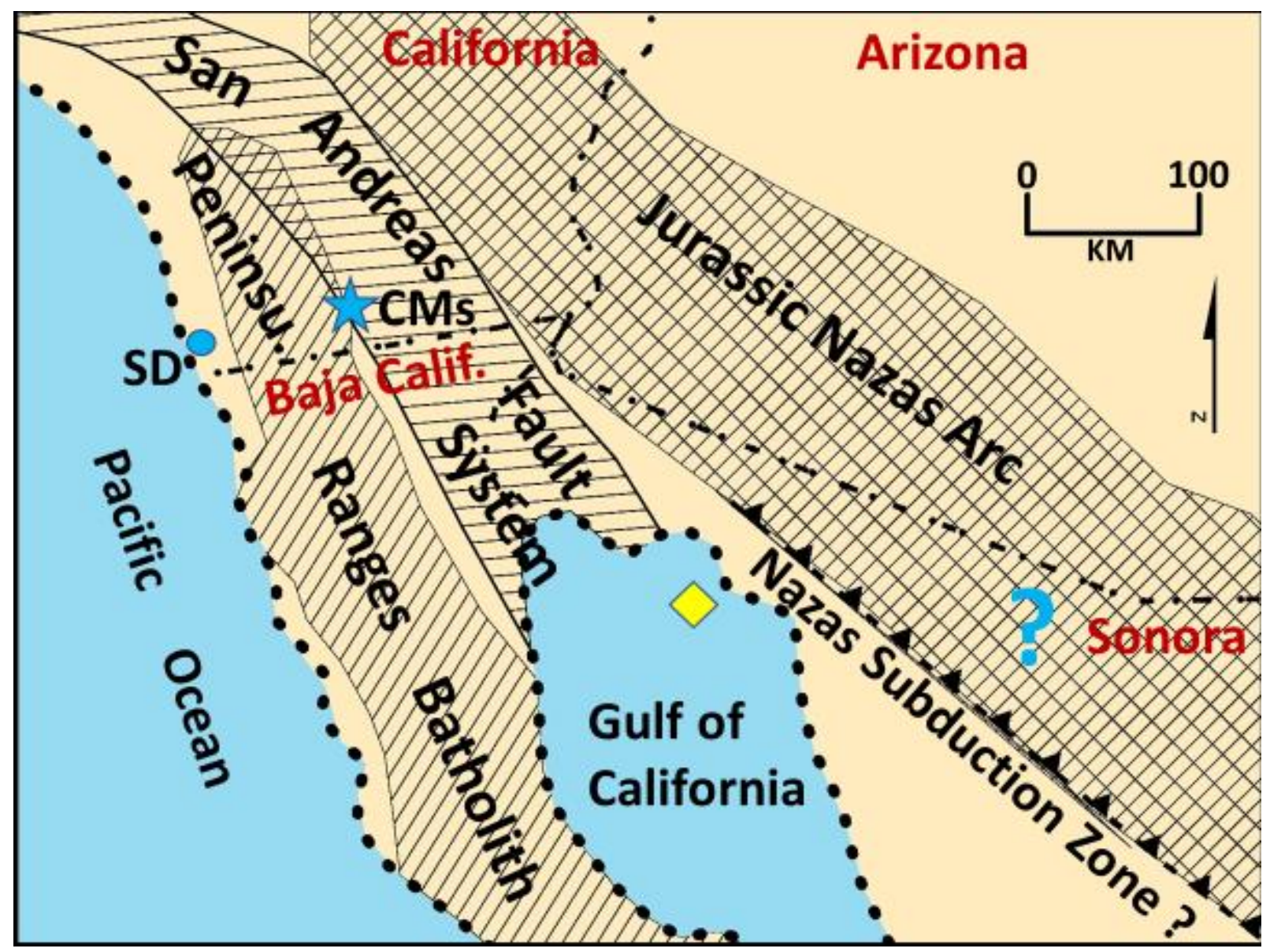

2. Simplified sketch map, modified from Titley and Zurcher (2008) showing a part of the Jurassic Nazas Arc with subduction zone (?), San Andreas Fault System, Peninsular Ranges Batholith, Coyote Mountains (CMs) and San Diego (SD). Blue Star is the present location of the CMs. Yellow Diamond is Winker and Kidwell's (1996) location of the CMs at 5.5 (?) Ma. Blue Question Mark is a possible location for the CMs in Sonora, Mexico. 


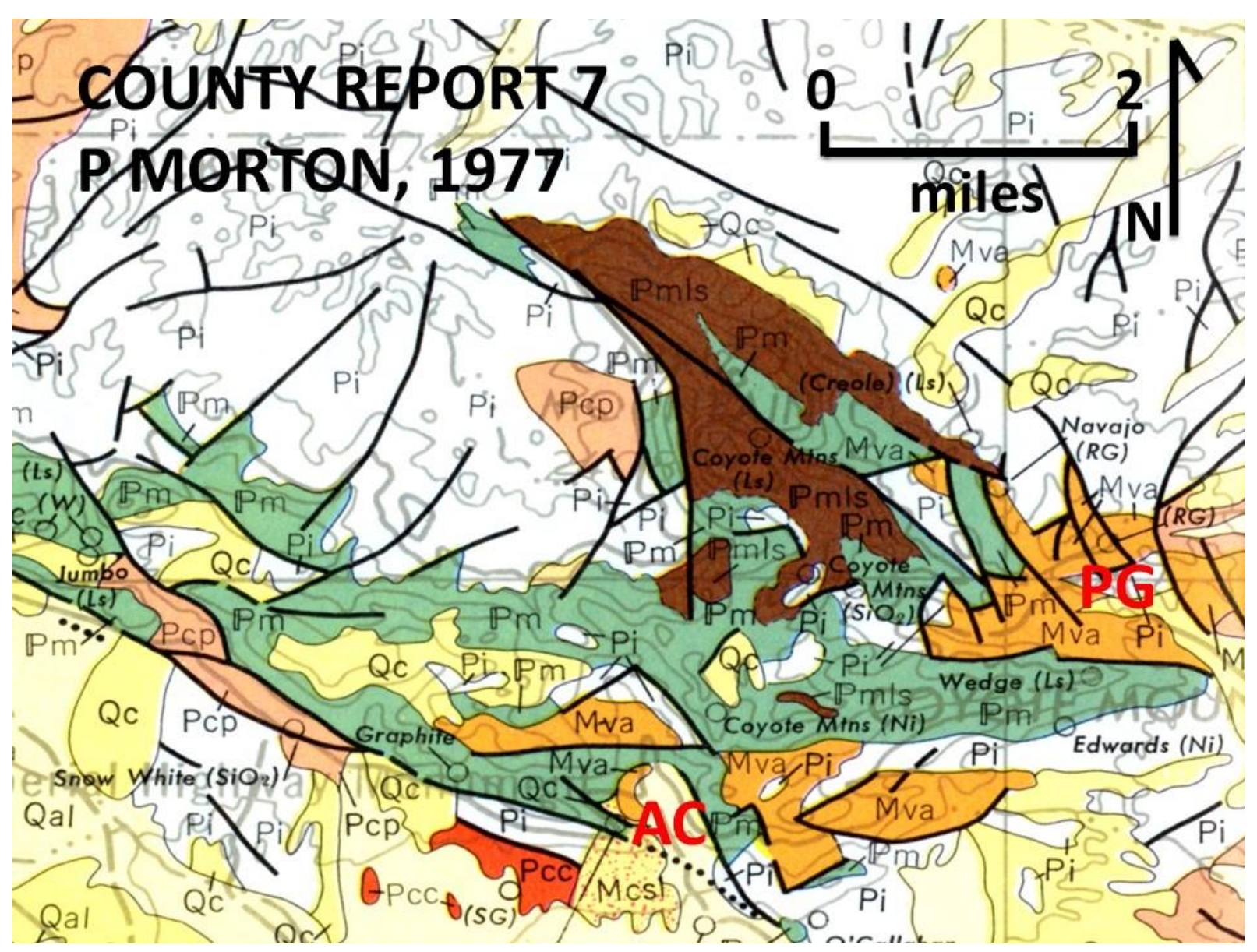

3. This portion of Morton's map is a good summary of the geological formations found in and around the CMs. Morton used portions of Dibblee's (1954) and Christensen's (1957) maps. Crystalline basement rocks are brown (marbles) and green (schists + Jurassic Intrusions). Simplified interpretations of the basement units: pillow basalts, Paleozoic (?) (Dibblee, 1954; Miller and Dockum (?) 1983) limestones, sandstones, mudstones, cherts, and gravels. Intruding, deforming and metamorphosing these Paleozoic (?) units are Jurassic igneous intrusive units dated with zircons (Morgan and Morgan, 2015). The oldest Tertiary units designated on the map are the volcanics of the Alverson Formation (zircon date of 17.1 Ma, Morgan et al., 2012) colored orange and labeled Mav. Next is the marine and non-marine units of the Imperial Group: colored white and labeled Pi. The non-marine Palm Spring Group is next, colored pink and labeled Pcc and Pcp. Units colored yellow and labeled Qc are Quaternary terrace gravels. The Qc units nonconformally on of the green metamorphics are Christensen's Quaternary Terraces. We have found these terraces interfingering with the Imperial Group (Morgan and Morgan, 2014, 2015). AC - Alverson Canyon. PG - Painted Gorge. 


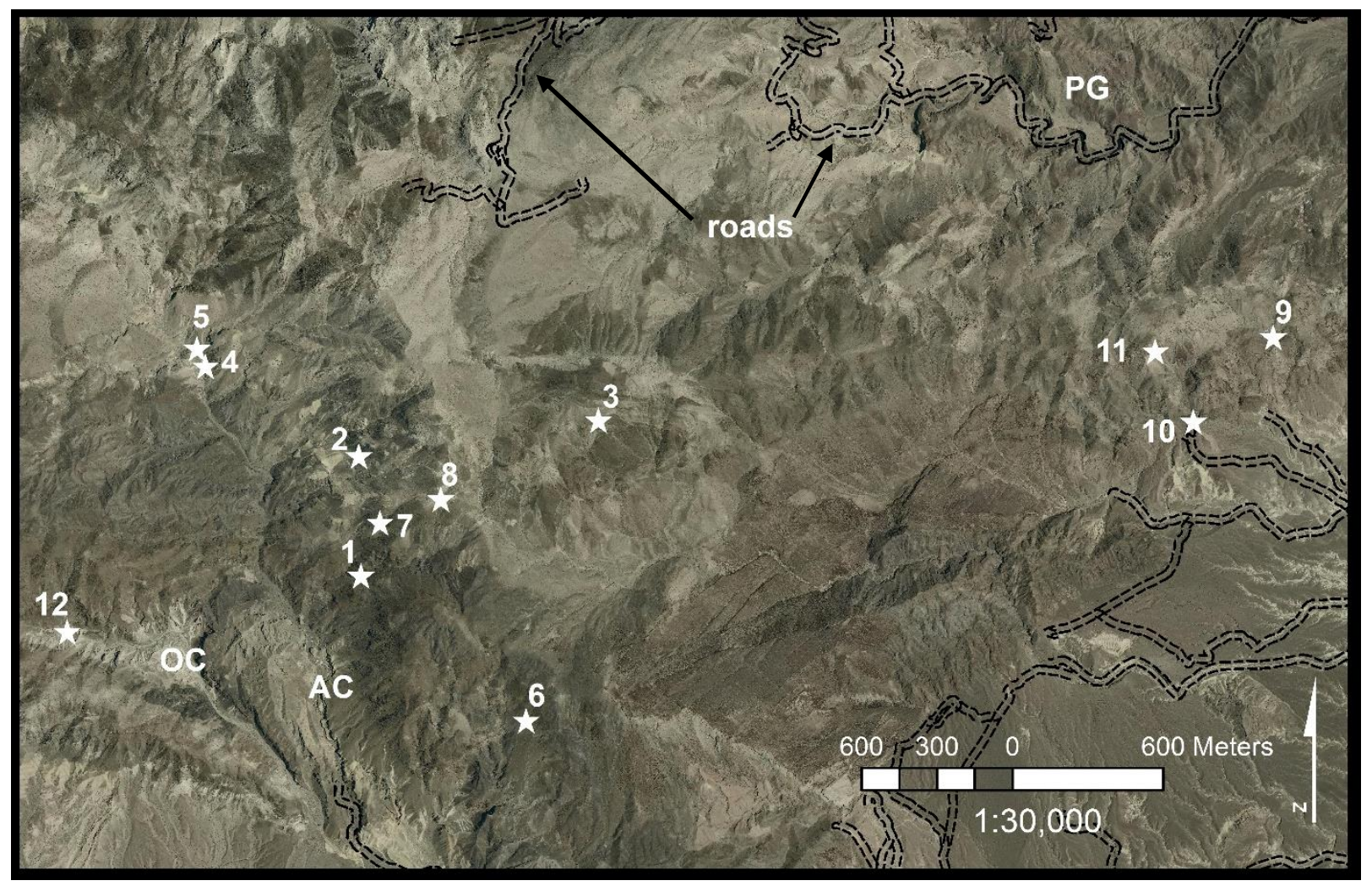

4. View on the southern CMs showing the locations of the zircon-dated granitic intrusions with roads. Most of the dated granitics are associated with Morton's green metamorphic unit. AC Alverson Canyon. OC-Ocotillo Canyon. PG - Painted Gorge.

$\begin{array}{cc}\text { Number } & \text { Zircon Age-Dates } \\ 1 & 164.1 \pm 2.8 \mathrm{Ma} \\ 2 & 163.9 \pm 2.8 \mathrm{Ma} \\ 3 & 163.8 \pm 3.0 \mathrm{Ma} \\ 4 & 163.2 \pm 2.4 \mathrm{Ma} \\ 5 & 162.4 \pm 2.2 \mathrm{Ma} \\ 6 & 162.2 \pm 3.5 \mathrm{Ma} \\ 7 & 161.9 \pm 2.4 \mathrm{Ma} \\ 8 & 161.4 \pm 2.6 \mathrm{Ma} \\ 9 & 160.2 \pm 2.0 \mathrm{Ma} \\ 10 & 153.6 \pm 1.4 \mathrm{Ma} \\ 11 & 151.2 \pm 1.3 \mathrm{Ma} \\ 12 & 138.8 \pm 0.96 \mathrm{Ma}\end{array}$




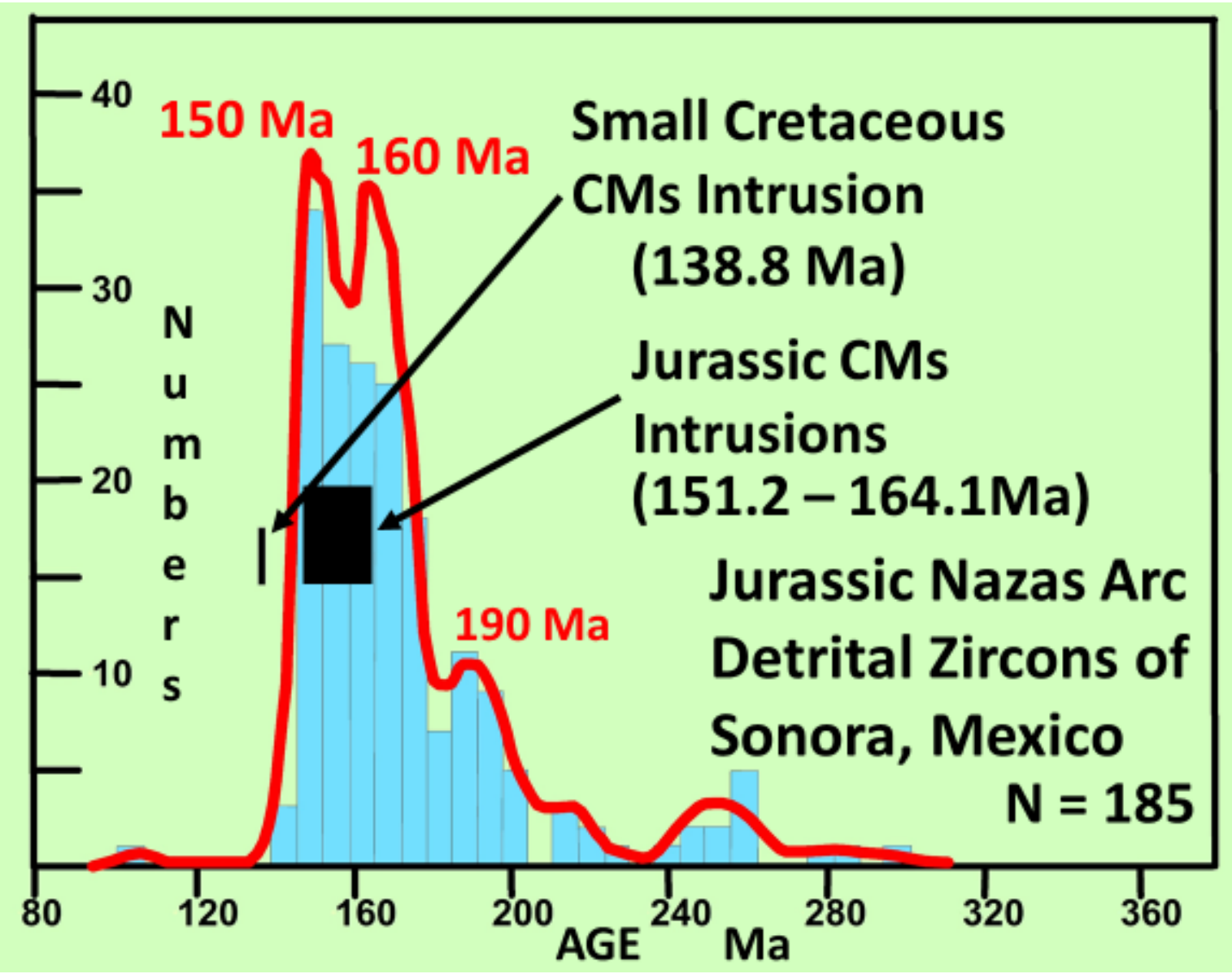

5. Figure modified from González-León et al. (2017). González-León et al.'s data shows the second (Jurassic) episode of magmatic activity of the Nazas Arc, which is inferred from detrital zircons of the Jurassic Sierra de Santa Rosa, Basomari, Lilt Formations (original data from González- León et al., 2009) combined with detrital zircons from the Cucurpe Formation (data from Mauel et al., 2011). The black rectangle represents the Jurassic intrusives found in the CMs. The thin, black, vertical bar to the left represents the single, small, Early Cretaceous intrusive found in the CMS. We have yet to find any granitic intrusives that are the age of the Peninsular Ranges Batholith ( 128-92 Ma, Hildebrand and Whalen, 2014b) in the CMs. 


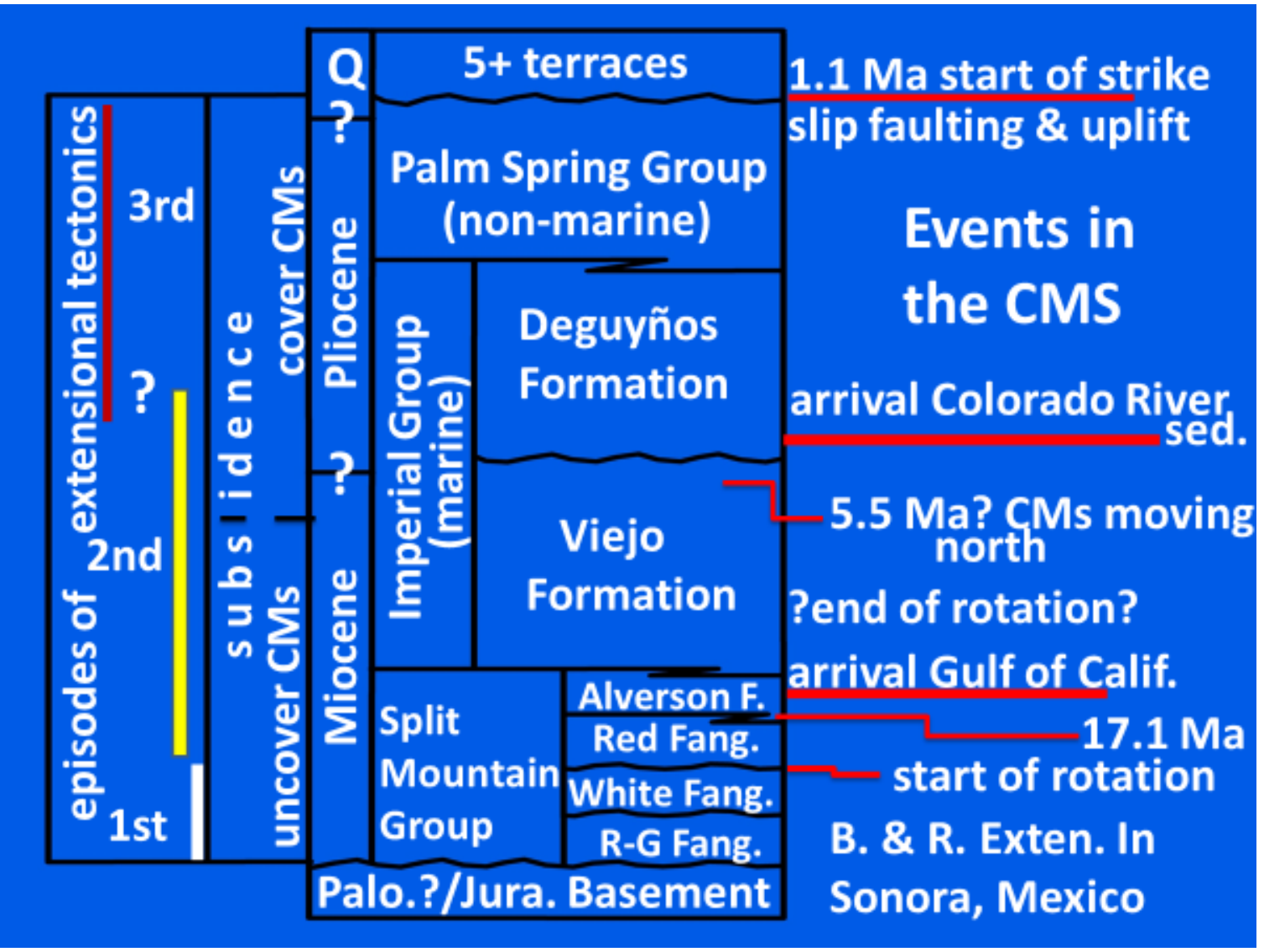

6. Three extensional tectonic episodes found in the CMs are shown in relational to group and formational units, their relationalship to each other and to events that have taken place in the CMs (Morgan and Morgan, 2017a). The white "?" mark between the second and third extensional episode questions the timing of the end of the second and the start of the third. These two epidotes may be one continues episode. The white "?" mark between the epochs is questioning where the corresponding age boundaries are in the sedimentary units. The 90 degrees of clockwise rotation in the CMs started at the end of the first episode of extension and ended during the deposition of the Viejo Formation (Morgan and Morgan, 2018b). B \& R - Basin and Range. F - Formation. Fang. - Fanglomerate. Q Quaternary. 


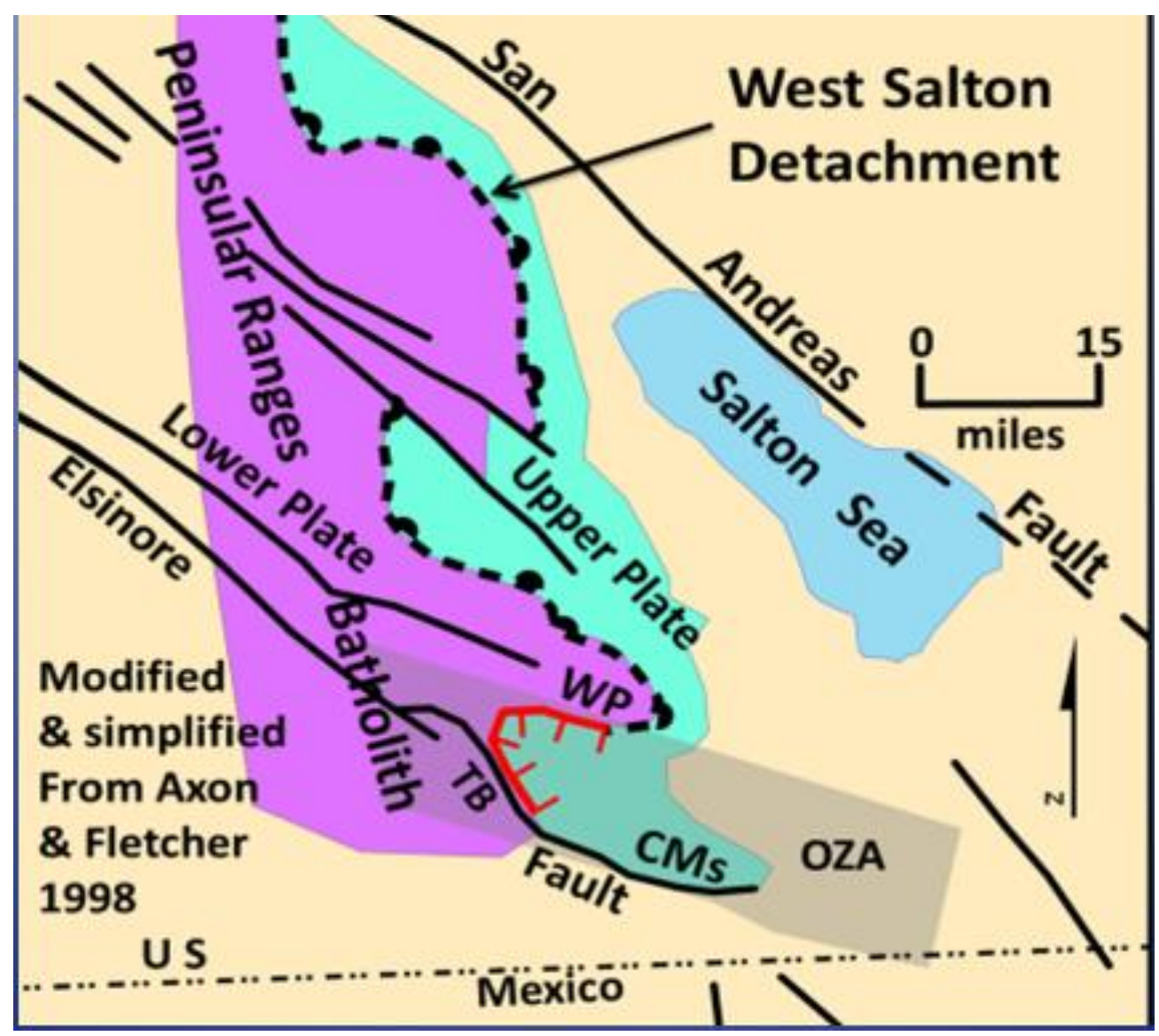

7. Sketch map of the upper and lower plates of the West Salton Detachment. In this area the western trace of the West Salton Detachment is the western edge of the Salton Trough. OZA - Ocotillo Zone of Accommodation (gray area). In later mapping (Axen et al., 2006) the West Salton Detachment was extended from Whale Peck (WP) to the Terra Blanca Mountains (TB). This implies that the OZA should be thinned to the Elsinore Fault. Pridmore and Frost (1992), Axen and Fletcher (1998) and Morgan and Morgan (2017a) all believe that the CMs are on the upper plate of a detachment. All the normal faults we have mapped in the CMs are possibly rooted to this detachment (Morgan and Morgan, 2017a). The lower plate and the upper plate are structurally tied together. If the lower plate is moved east in a reconstruction, the upper plate has to follow. With the removal of the extension of the Basin and Range Province in Sonora, the Peninsular Ranges Batholith would be next to the Sonoran Block along a geosuture (?). This geosuture may have be a part of the Nazas Arc Subduction Zone(?) (?). We believe the Peninsular Ranges Batholith Block wound under-thrust the Sonoran Block. 


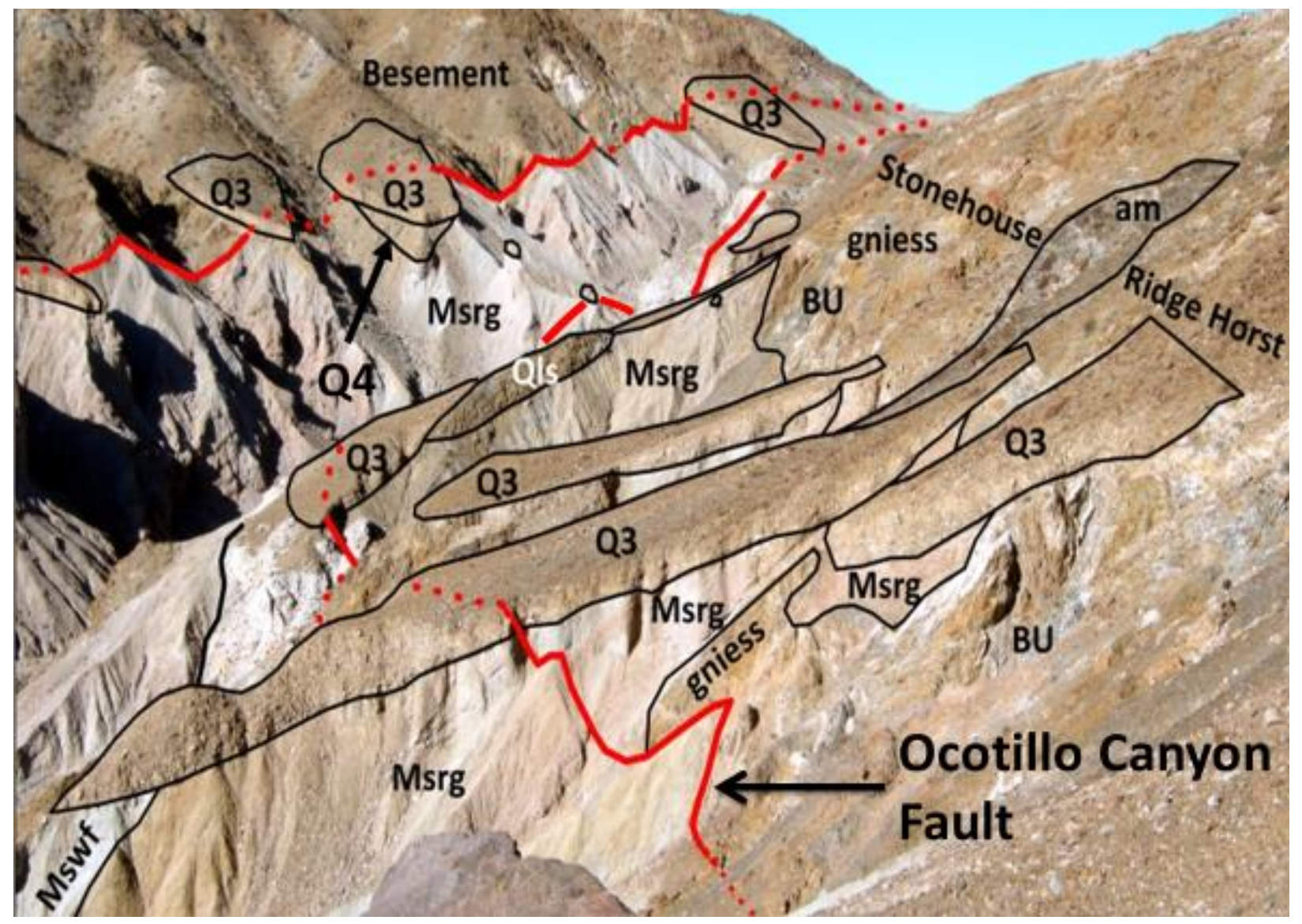

7. Looking west at the northern part of Ocotillo Canyon (first canyon west of Alverson Canyon). The normal Ocotillo Fault is the northern boundary of a halfgraben that formed during the first episode of extension tectonics, while the CMs were in Sonora, Mexico (Morgan and Morgan, 2018a). The Ocotillo Canyon Fault does not cut the volcanics of the 17.1 Ma Alverson Formation. The only extensional tectonics taking place before $17.1 \mathrm{Ma}$ in southwestern North America was in the Basin and Range Province. A southern and younger fault truncated and removes the southern part of the half-graben. Both faults can be seen converging to the west as they narrow the graben. Normal faults of the second extensional episode cut the Ocotillo Canyon Fault and the corresponding Stonehouse Ridge Horst (Morgan and Morgan, 2018b). am - amphibolite. BU - buttress unconformity. Q3 - Quaternary Terrace 3. Q4-Quaternity Terrace 4. Qls Quaternary landslide. Msrg - Miocene Red-Green Fanglomerate and Mswf Miocene White Fanglomerate; both a part of the Split Mountain Group (SMG). 


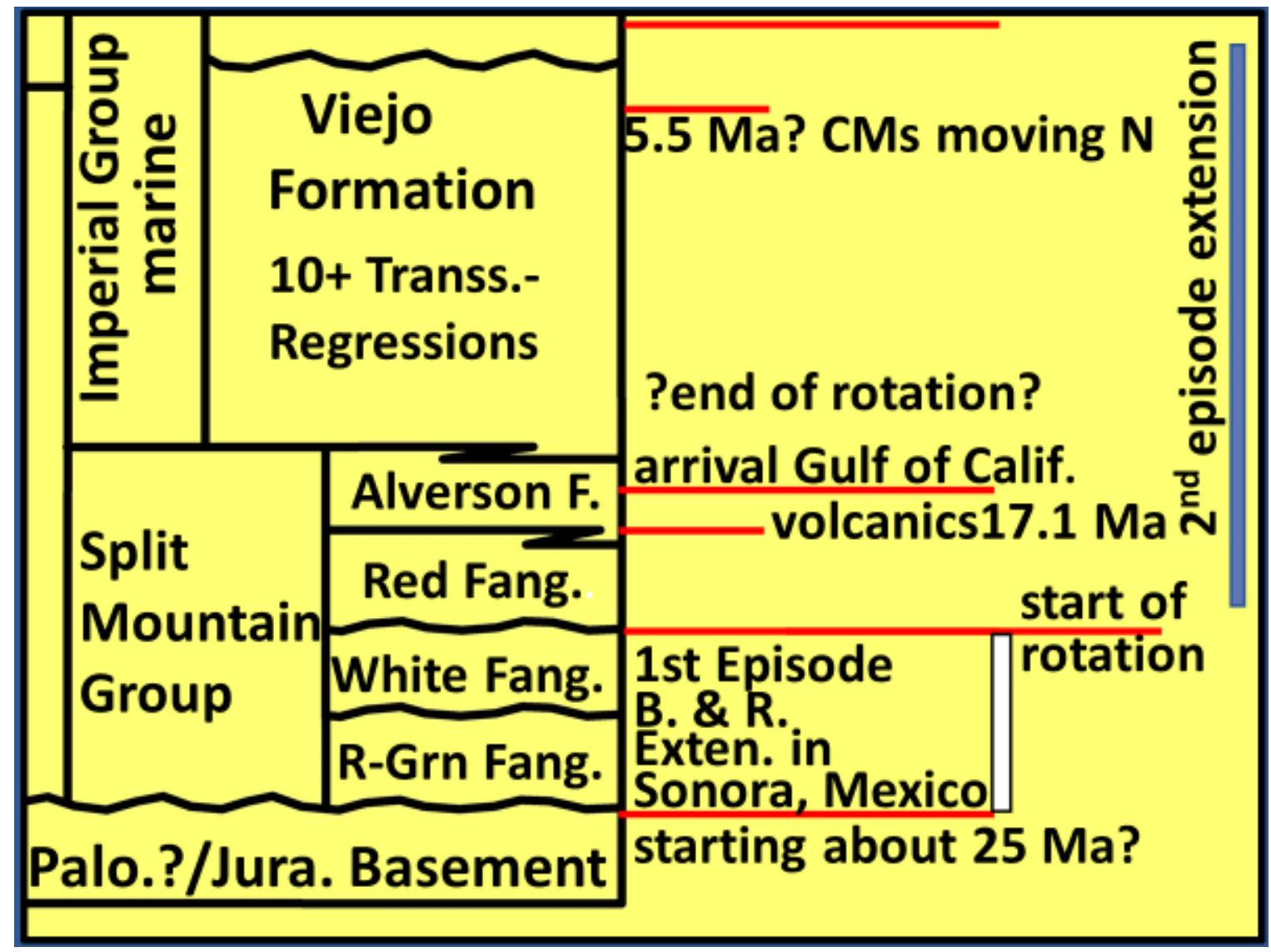

9. At about $25 \mathrm{Ma}$ Basin and Range extension stated in Sonora, Mexico (Nourse et al., 1994). During this extension the Red-Green (R-Gen) and White Fanglomerates of the SMG were syn-extensionally deposited in the CMs. The Red Fanglomerate and the volcanics of the Alverson Formation of the SMG are syn-extensionally related to the second episode found in the CMs. The Red Fanglomerate interfingers with the Alverson Formation (Mendenhall, 1910; Christensen, 1957). The Viejo Formation interfingers with the Alverson (Woodring, 1931; Morgan and Morgan, 2014, 2016). This second episode appears to be related to the continuing Basin and Range extension and the arrival ( 17.1 Ma) of the Gulf of California (Viejo Formation). The continuing rotation of the CMs is recorded at two paleomagnetic (Mace,1981) sites located in the volcanics of the Alverson Formation on the stable (?) Stonehouse Ridge Horst ( $34^{\circ}$ and $70^{\circ}$ of clockwise rotation). Rotation ends sometime during the deposition of the Viejo Formation. B \& $\mathbf{R}-$ Basin and Range. 


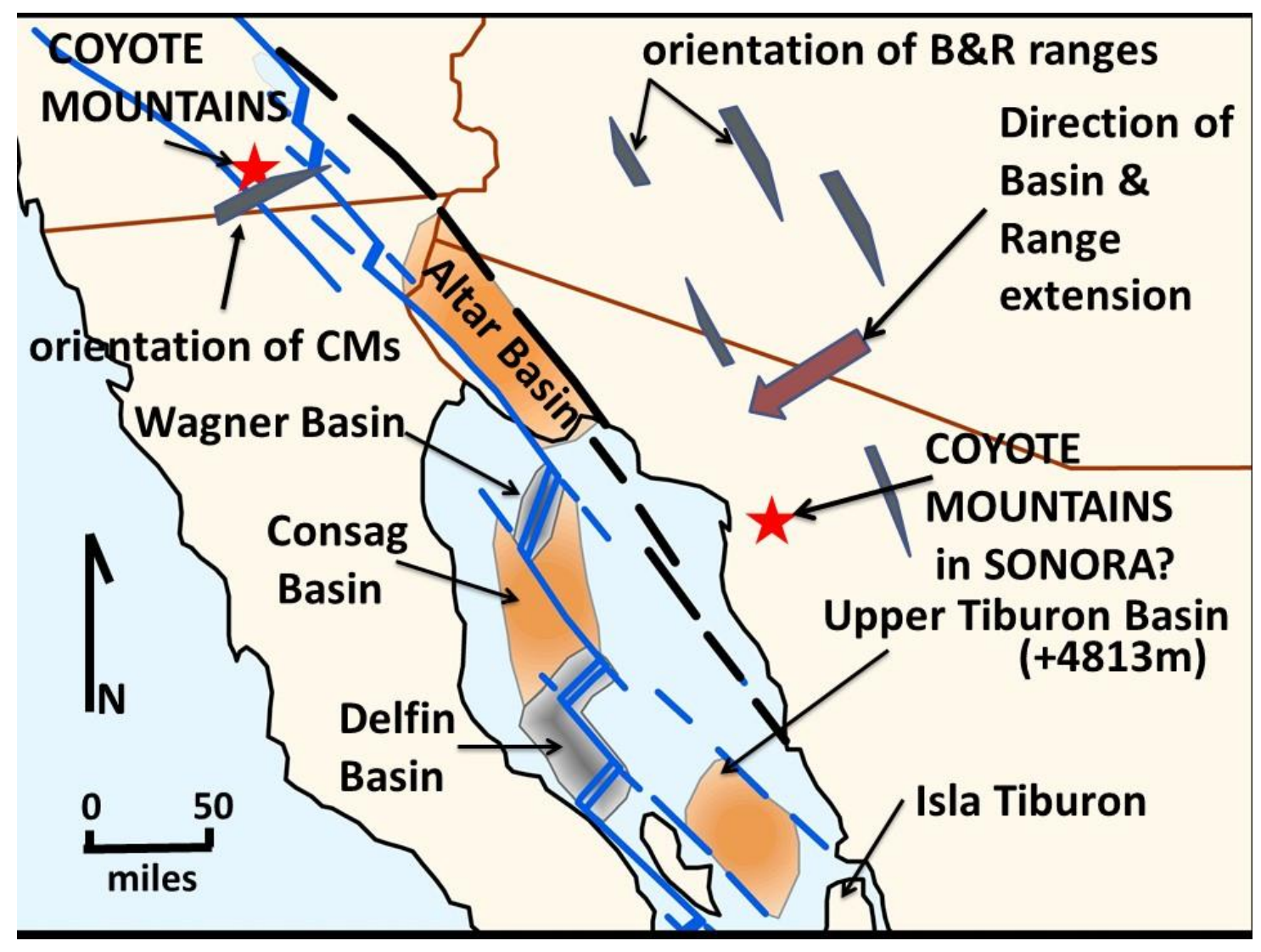

10. Map showing the present-day northern part of the Gulf of California. Helenes et al. (2009) suggest that the proto (young) gulf of California filled basins produced during the Miocene extension associated with the Basin and Range Province in Sonora. Brown areas (Upper Tiburon, Consag and Altar Basins) are some of the older marine basins associated with this Basin and Range extension and subsidence. The Old Plate Boundary is also associated with this Miocene extension. McDowell et al. (1997) observed that the Basin and Range extension in Sonora continued and was "coeval with initial evolution" of the rightlateral transtensional tectonics that produced the Gulf of California. Our second episode of extension in the CMs corresponds to McDowell's observation (Morgan and Morgan, 2017a). The Basin and Range extension has to move the CMs west of the New Plate Boundary before $5.5 \mathrm{Ma}$ when the new boundary is established. The right-lateral transtensional faulting then can move the $\mathrm{CMs}$ to the western edge of the Salton Trough, east of the Peninsular Ranges Batholith. 


\section{Inferences:}

Jurassic granitic intrusions in the $\mathrm{CMs}$ are associated with the Jurassic Nazas Arc and not the Cretaceous Peninsular Ranges Batholith.

Early to Mid-Miocene extension, before 17.1 Ma, of the Basin and Range Provence moved the CMs and the Peninsular Ranges Batholith west.

Before extension, the Peninsular Ranges Batholith was suture to Sonora, possibly along the Nazas Arc Subduction Zone(?). During collision with the Cretaceous Peninsular Ranges Batholith the Sonoran Block was thrust up and over the Peninsular Ranges Batholith.

Extensional tectonics and subsidence may have continued until $\sim 1.1 \mathrm{Ma}$ in the CMs.

Extensional tectonics moved the CMs west of the New Plate Boundary before $5.5 \mathrm{Ma}$. Then right-lateral transtensional faulting associated with the San Andreas System moved the CMs northwest to their present location in the western Salton Trough.

The Peninsular Ranges Batholith moved in unison with the CMs.

\section{Acknowledgments}

Zircons were dated with the help of Nicky Giesler and Mark Pecha at the Arizona LaserChron Center, University of Arizona, Tucson. Thanks to those who helped in many different was: John Prall, Bill Elliott, Mike Hart, Ann Bykerk-Kauffman, Eric Frost, Susan Kidwell, Stephen Schellenberg, Monte Marshall, Thomas Zmudka, Gordon Gastil, Gary Axen, Larry Busch, Charles Winker, Jerry Treiman, Jim Senn and the BLM, El Centro Office for a mapping permit.

\section{References}

Axen, G. J., and Fletcher, J. M., 1998, Late Miocene-Pliocene extensional faulting, northern Gulf of California, Mexico, and Salton Trough, California: in International Geological Review, V. 40, p. 217-244.

Axen, G. J.; Janecke, S.; Steely, A.; Shirvell, C.; Fluette, A.; Kairouz, M.; Housen, B.;

Stockli, D.; Dorsey, R.; Grove, M., 2006, The West Salton Detachment Fault, Salton 
Trough California: a Primary Low-Angle Normal Fault in an Evolving Dextral Wrench Zone: American Geophysical Union, Fall Meeting, abstract id. T41D-1602.

Christensen, A. D., 1957, Part of the geology of the Coyote Mountains area, Imperial County, California: Unpublished M.S. thesis, University of California at Los Angeles, 188p.

Dibblee, T. W., 1954, Geology of the Imperial Valley region, California, in Jahns, R. H., ed., Geology of southern California: California Division Mines Bulletin, v. 170, p. 21-28.

González-León, C. M., Stanley, Jr., G.D., Lawton, T. F., Pálfy, J., Hodges, M. S., 2017, The Triassic/Jurassic boundary and the Jurassic stratigraphy and biostratigraphy of northern Sonora, northwest Mexico: BOL. SOC. GEOL. MEX., VOL. 69 NO. 3, P. $711-738$.

González-León, C.M., Valencia, V.A., Lawton, T.F., Amato, J., Gehrels, G.E., Leggett, W.J., Montijo-Contreras, O., Fernández, M.A., 2009, The lower Mesozoic record of detrital zircon U-Pb geochronology of Sonora, Mexico and its paleogeographic implications: Revista Mexicana de Ciencias Geológicas, 26, 301-314.

Helenes, J., Carreno A.L., and Carrillo R.M., (2009), Middle to late Miocene chronostratigraphy and development of the northern Gulf of California, Mar. Micropaleontol., 72, 10.

Hildebrand, R.S., and Whalen, J.B., 2014, Arc and slab-failure magmatism in Cordilleran batholiths II - The Cretaceous Peninsular Ranges batholith of Southern and Baja California: Paul Hoffman Volume, Geoscience Canada, v. 41, p. 399-458.

Mace, N.W., 1981, A paleomagnetic study of the Miocene Alverson Volcanics of the Coyote Mountains, western Salton Trough, California: a Master's Thesis at San Diego State University, 142p.

Mauel, D.J., Lawton, T.F., González-León, C.M., Iriondo, A., Amato, J.M., 2011, Stratigraphy and age of Upper Jurassic strata in north-central Sonora, Mexico: Southwestern Laurentian record of crustal extension and tectonic transition: Geosphere 7, 390-414.

McDowell, F.W., Roldán-Quintana, J., and Amaya-Martínez, R., 1997, Interrelationship of sedimentary and volcanic deposits associated with Tertiary extension in Sonora, Mexico: Geological Society of America Bulletin, v. 109, p. 1349-1360, doi: 10.1130/0016-7606(1997)109<1349: IOSAVD>2.3. CO.

Mendenhall, W. L., 1910, Notes on the Geology of Carrizo Mountain and vicinity, San Diego County, California: Journal of Geology, v. 18, p. 336-355. 
Miller, R, H., and Dockum, M. S., 1983, Ordovician conodonts from metamorphosed carbonates of the Salton Trough, California: Geology, v. 11, p. 410-412.

Morgan, G. J., and Morgan, J, R., 2014, A 2014 update of an Overview of the Geology and Geological Problems of the Coyote Mountains, Salton Trough, Imperial County, southern California. In: Coast to Cactus, Geology and Tectonics San Diego to Salton Trough, California, Morton, J. B., Editor, P. 135-148.

Morgan, G. J., and Morgan, J. R., 2015, Overview of the Geology of the southern Coyote Mountains, Salton Trough, Imperial County, southern California. In Wagner, R., ed., Geology of the Coyote Mountains, southern California: San Diego Association of Geologists, p.77-87.

Morgan, G. J. and Morgan, J.R., 2016, Viejo Formation: a new formation for the Imperial Group sediments in the southern Coyote Mountains, Salton Trough, southern California, GSA Cordilleran Section, Abstract Paper No. 28-10.

Morgan, G. J. and Morgan, J.R., 2017a, Miocene(?) to late Pleistocene Extensional Tectonics in the Coyote Mountains, western Salton Trough, southern California: Ecsy Does It, Revisiting the eastern California Shear Zone, 2017 Desert Symposium Field Guide and Proceedings; Robert E Reynolds, editor; California State University Desert Studies Consortium, p, 194-206.

Morgan, G, J., and Morgan, J. R., 2018b, Extensional Tectonics, a Slab Window and the arrival of the Gulf of California about 17Ma, while the Coyote Mountains of southern California, USA undergo $90^{\circ}$ clockwise rotation in Sonora, Mexico: Geological Society of America Abstracts with Programs. Vol. 50, No. 5, ISSN 00167592 doi: 10.1130/abs/2018RM-314078

Morgan, J. R., Morgan, G. J. and Pecha, M., 2012, U/Pb dating of tuffs from the Alverson Volcanics in the Fossil Canyon and Painted Gorge areas of the Coyote Mountains, western Salton Trough, California, GSA, Abstract and Programs, Vol. 44, No. 3, p. 22.

Morton, P. K., 1977, Geology and mineral resources of Imperial County, California: California Division of Mining and Geology, County Report No.7.

Nourse, J. A., Anderson. T. A., and Silver, L. T., 1994, Tertiary metamorphic core complexes in Sonora, northwest Mexico: Tectonics, v.13, p. 1161-1182.

Pridmore, C., and Frost, E., 1992, California's Extended Past, California Geology, v.45, p. 
3-17.

Ruisaard, C. I., 1979, Stratigraphy of the Miocene Alverson Formation, Imperial County, California: Master Thesis, San Diego State University, 125p.

Steely, A. N., Janecke, S. U., Dorsey, R. J., and Axen, G. J., 2009, Early Pleistocene initiation of the San Felipe fault zone, SW Salton Trough, during reorganization of the San Andreas Fault System: Geological Society of America Bulletin, v. 121, P. 663-687, doi. 10.1130/B26239.1.

Titley, S.R., and Zürcher, Lukas, 2008, Regional geology and ore-deposit styles of the trans-border region, southwestern North America, in Spencer, J.E., and Titley, S.R., eds., Ores and orogenesis: Circum-Pacific tectonics, geologic evolution, and ore deposits: Arizona Geological Society Digest 22, p. 275-294.

Winker, C. D., and Kidwell, S. M., 1996, Stratigraphy of a marine rift basin: Neogene of the western Salton Trough, California, in Abbott, P. L., and Cooper, J. D., eds., Field Conference Guidebook and Volume for the Annual Convention: San Diego, California, American Association of Petroleum Geologists, Pacific Section, p. 295336.

Woodring, W. P., 1931, Distribution and age of the Tertiary Deposits of the Colorado Desert: Carnegie Institution of Washington Publication 148, p. 1-25. 